\title{
Bioavailability of Cerium Oxide Nanoparticles to Raphanus sativus L. in Two Soils
}

\author{
Weilan Zhang ${ }^{1}$, Craig Musante ${ }^{2}$, Jason C. White ${ }^{2}$, Paul Schwab ${ }^{3}$, Qiang, Wang ${ }^{4}$, Stephen \\ D. Ebbs ${ }^{5}$, Xingmao $\mathrm{Ma}^{1, *}$
}




\section{Abstract}

26 Cerium oxide nanoparticles $\left(\mathrm{CeO}_{2} \mathrm{NP}\right)$ are a common component of many

27 commercial products. Due to the general concerns over the potential toxicity of

28 engineered nanoparticles (ENPs), the phytotoxicity and in planta accumulation of $\mathrm{CeO}_{2}$

29 NPs have been broadly investigated. However, most previous studies were conducted in

30 hydroponic systems and with grain crops. For a few studies performed with soil grown

31 plants, the impact of soil properties on the fate and transport of $\mathrm{CeO}_{2} \mathrm{NPs}$ was generally

32 ignored even though numerous previous studies indicate that soil properties play a critical

33 role in the fate and transport of environmental pollutants. The objectives of this study

34 were to evaluate the soil fractionation and bioavailability of $\mathrm{CeO}_{2} \mathrm{NPs}$ to Raphanus

35 sativus $\mathrm{L}$ (radish) in two soil types. Our results showed that the silty loam contained

36 slightly higher exchangeable fraction (F1) of cerium element than did loamy sand soil,

37 but significantly lower reducible (F2) and oxidizable (F3) fractions as $\mathrm{CeO}_{2} \mathrm{NPs}$

38 concentration increased. $\mathrm{CeO}_{2} \mathrm{NPs}$ associated with silicate minerals or the residue

39 fraction (F4) dominated in both soils. The cerium concentration in radish storage root

40 showed linear correlation with the sum of the first three fractions $\left(r^{2}=0.98\right.$ and 0.78 for

41 loamy sand and silty loam respectively). However, the cerium content in radish shoots

42 only exhibited strong correlations with $\mathrm{F} 1\left(\mathrm{r}^{2}=0.97\right.$ and 0.89 for loamy sand and silty

43 loam respectively). Overall, the results demonstrated that soil properties are important

44 factors governing the distribution of $\mathrm{CeO}_{2} \mathrm{NPs}$ in soil and subsequent bioavailability to 45 plants.

47 Keywords: cerium oxide nanoparticles, radish, bioavailability, soil fractionation 


\section{Introduction}

49 As the world's most abundant rare earth element, cerium is widely used in

50 industries both in free metal and oxide form (Naumov, 2008; Masui et al., 2002). Thanks

51 to the large specific surface area and rich redox chemistry, cerium oxide nanoparticles

$52\left(\mathrm{CeO}_{2} \mathrm{NPs}\right)$ have been used as catalysts, electrolyte materials and fuel additives (Zhang et

53 al., 2002). The increasing popularity of $\mathrm{CeO}_{2}$ NPs in industry has caused concern over

54 their potential toxicity in the environment. There have been many reports that indicate

55 potential toxicity of $\mathrm{CeO}_{2}$ NPs to bacteria, fish, and mammalian cells (Pelletier et al.,

56 2010; Rosenkranz et al., 2012). The potential risks of $\mathrm{CeO}_{2}$ NPs to plants, a critical food

57 source for humans, have also been investigated. However, previous studies were mainly

58 focused on the uptake and accumulation of $\mathrm{CeO}_{2} \mathrm{NPs}$ by grain crops and aboveground

59 vegetables in hydroponic systems. For instance, López-Moreno et al. (López-Moreno et

60 al., 2010) showed that intact $\mathrm{CeO}_{2}$ NPs were taken up by soybean roots in hydroponic

61 systems without subsequent biotransformation. Zhang et al. (Zhang et al., 2011) also

62 reported that cucumber (Cucumis sativus L.) root could take up $\mathrm{CeO}_{2} \mathrm{NPs}$ and transport

63 them to the shoots. However, later investigations suggested that $\mathrm{CeO}_{2} \mathrm{NPs}$ may release

$64 \mathrm{Ce}^{3+}$ on root surface and uptake of $\mathrm{Ce}^{3+}$ rather than $\mathrm{CeO}_{2} \mathrm{NPs}$ might be the primary

65 pathwyay for plant upktae of $\mathrm{CeO}_{2}$ NPs (Rui et al., 2015; Ma et al., 2015; Schwabe et al.,

66 2015). Although hydroponic studies provide valuable information on the potential

67 mechanisms of plant uptake and accumulation of $\mathrm{CeO}_{2} \mathrm{NPs}$, increasing efforts are

68 dedicated to elucidating the fate and impact of $\mathrm{CeO}_{2} \mathrm{NPs}$ in soil to obtain a more realistic

69 understanding of the fate and impact of $\mathrm{CeO}_{2}$ NPs.

$70 \quad$ For example, after tomato plants were irrigated with 0.1 to $10 \mathrm{mg} / \mathrm{L}$ of $\mathrm{CeO}_{2} \mathrm{NPs}$ 
71 solutions, Wang et al. (Wang et al., 2012) reported that Ce was accumulated in tomato

72 (Solanum lycopersicum L.) roots and shoots, including the edible tissues, with the root

73 being the primary tissue of accumulation. Zhao et al. (Zhao et al., 2015) also reported low

74 translocation of $\mathrm{CeO}_{2}$ NPs from root to shoot in corn plants (Zea mays L.) and noticed

75 that $800 \mathrm{mg} / \mathrm{kg} \mathrm{CeO} \mathrm{CPs}_{2}$ did not affect plant photosynthesis throughout the exposure but

76 significantly reduced the corn yield. Another recent study demonstrated that $\mathrm{CeO}_{2} \mathrm{NPs}$

77 did not affect the growth of lettuce (Lactuca sativa $\mathrm{L}$.) at low concentrations $(50 \mathrm{mg} / \mathrm{kg}$

78 and $100 \mathrm{mg} / \mathrm{kg}$ ) in potting soil, but significantly inhibited biomass production and

79 disrupted plant stress responses at $1000 \mathrm{mg} / \mathrm{kg}$ (Gui et al., 2015). While these soil-based

80 studies provide significant new information on the fate and impact of $\mathrm{CeO}_{2} \mathrm{NPs}$ in the

81 ecosystem, none of the previous studies has closely examined the impact of soil

82 properties on the toxicity and bioavailability of $\mathrm{CeO}_{2} \mathrm{NPs}$ to terrestrial plants. Plant

83 uptake of metals in soil depends on both the soluble fraction of total metal and the

84 capability of soil to release the metals and both factors are considerably affected by the

85 soil properties (Backes et al., 1995). Previous research has shown that metal mobility in

86 soil is governed by many factors including the soil characteristics (e.g. soil texture, $\mathrm{pH}$,

87 and organic matter content); the nature of the contaminants (e.g. the chemical forms of

88 pollutants and the binding state); and the environmental conditions (e.g. acidification,

89 redox processes, temperature, and water regime) (Sahuquillo et al., 2003).

90 In recent decades, several extraction methods have been developed to evaluate the

91 mobility of metals in soil. Sequential selective extraction is defined as the use of a series

92 of selective reagents to solubilize the solid material successively into specific fractions

93 (Gleyzes et al., 2002). A three-step sequential extraction procedure for soil and sediment 
94 analysis known as the BCR (Bureau Commune de Reference of the European

95 Commission) method, proposed in 1993 (Ure et al., 1993) and later modified by Rauret et

96 al in 1999 (Rauret et al., 1999) is widely used for the determination of extractable trace

97 metals in soils and sediments. This three-step sequential extraction method separates the

98 metal of interest into four fractions: the exchangeable, water/acid soluble metal (F1); the

99 metal bound to Fe-Mn oxides (F2); the metal bound to organic matter (F3) and the metal

100 bound to silicate minerals in the residual fraction (F4) (Rao et al., 2010; Sahuquillo et al.,

101 2003; Li et al., 2010). According to the research of Li et al. (Li et al., 2010), F1

102 represents the most active, mobile and bioavailable phase of the metal. These authors

103 used the BCR method to study the bioavailability of $\mathrm{Zn}, \mathrm{Cu}, \mathrm{Pb} \mathrm{Cd}, \mathrm{Hg}$, and As in topsoil

104 and found that soil physicochemical properties (e.g. $\mathrm{pH}$, organic matter, and clay content)

105 affected metal fractionation in soil and their bioavailability to plants. Zhong et al. (Zhong

106 et al., 2011) suggested that the first three fractions of the metals in soil were the

107 potentially bioavailable and hazardous fractions to plants. The successful application of

108 the BCR method to estimate the bioavailability of heavy metals in soil to plants provides

109 a potentially useful method to evaluate the availability of engineered metallic

110 nanoparticles under similar exposure scenarios.

111 Radish (Raphanus sativus L.) is a popular vegetable with high global

112 consumption and can mature in three to four weeks under favorable growth conditions.

113 Radish is also an underground vegetable, with its edible tissues directly exposed to $\mathrm{CeO}_{2}$

114 NPs in soil. Therefore, radish may accumulate high concentrations of ENPs in their

115 edible tissues. A previous study indeed demonstrated that the radish tubes grown in a

116 loamy sand soil with 250 and $500 \mathrm{mg} / \mathrm{kg}$ of $\mathrm{CeO}_{2} \mathrm{NPs}$ accumulated high concentrations 
117 of Ce, posing potential risks for human exposure (Corral-Diaz et al., 2014). However,

118 detailed distribution of $\mathrm{Ce}$ in the tubes and the role of soil properties were not reported in

119 that study. The objectives of this investigation were to (1) use the BCR sequential

120 extraction method to evaluate the fractionation of $\mathrm{CeO}_{2} \mathrm{NPs}$ in two types of soil, (2)

121 assess the bioavailability of $\mathrm{CeO}_{2} \mathrm{NPs}$ to radish roots and (3) determine the impact of soil

122 type on the root to shoot translocation of $\mathrm{CeO}_{2} \mathrm{NPs}$ and their distribution in plant tissues.

\section{Materials and Methods}

\section{Chemicals}

126 A dispersion of bare $\mathrm{CeO}_{2} \mathrm{NPs}\left(10 \mathrm{wt}\right.$ \% in $\mathrm{H}_{2} \mathrm{O},<25 \mathrm{~nm}$ particle size) was

127 purchased from Sigma-Aldrich (St. Louis, MO). The shape, size and size distribution

128 were determined by a Tecnai G2 F20 transmission electron microscope (TEM) (FEI,

129 Hillsboro, Oregon) and are shown in Figure 1. Most of the nanoparticles had quadrilateral

130 or polygonal shapes and fell in the size range of $10-25 \mathrm{~nm}$ in diameter with an average

131 nanoparticle size of $19.1 \mathrm{~nm}$. The size distribution was obtained by measuring 112

132 individual nanoparticles on the TEM image with ImageJ. The hydrodynamic diameter

133 and zeta potential of $\mathrm{CeO}_{2} \mathrm{NPs}$ at $500 \mathrm{mg} / \mathrm{L}$ in water were $107.3 \mathrm{~nm}$ and $45 \pm 0.41 \mathrm{mV}$

134 respectively, as measured by a dynamic light scattering instrument (Malvern Zetasizer

135 Nano-ZS90, Westborough, MA). The surface speciation of $\mathrm{CeO}_{2} \mathrm{NPs}$ was investigated

136 with an X-ray photoelectron spectroscopy (XPS) (Omicron multiprobe MXPS system,

137 Scienta Omicron, Germany). The XPS spectra of the surface of $\mathrm{CeO}_{2} \mathrm{NPs}$ was shown in

138 Figure 1c. The results indicated that $12.4 \%$ of $\mathrm{Ce}$ on the surface was in the form of $\mathrm{Ce}^{3+}$,

139 as calculated through the XPS peak fitting software XPSPEAK 4.1. 
141 appropriate amount of the modified Hoagland's basal salt mixture purchased from

142 Phytotechnology Laboratories (Lenexa, KS) in deionized (DI) water.

\section{Soil characterization}

144 Two types of soil were used in this study: (1) commercially-purchased topsoil

145 (Timberline Top Soil, Oldcastle Inc., Atlanta, GA); (2) an agricultural soil collected from

146 a farmland associated with Southern Illinois University (Carbondale, IL). Due to the

147 different weight percentages of sand, silt and clay in these two soils, the topsoil was

148 classified as loamy sand and the local soil was classified as silty loam according to the

149 USDA soil texture classification. The weight percentages of sand, silt, and clay were

150 determined through wet sieve analysis and hydrometer test (Bouyoucos, 1962). The

151 results for both soils are shown in Supplementary Table 1.

152 The Deutsches Institut für Normung (DIN) 19684-1 method was adopted for the

153 measurement of soil $\mathrm{pH}$. One hundred $\mathrm{mL}$ deionized water was mixed with $40 \mathrm{~g}$ of air-

154 dried soil at the speed of $250 \mathrm{rpm}$ (solid-liquid mass ratio 1:2.5). The mixture was shaken

155 for five minutes and allowed to settle for two hr. The $\mathrm{pH}$ was then measured with a $\mathrm{pH}$

156 meter (Thermo Scientific Orion ROSS Ultra pH/ATC Triode, Orion Star A325). The pH

157 of loamy sand was 6.87 and the $\mathrm{pH}$ of silty loam was 6.58 .

158 The ASTM D 2974 method (Standard Test Methods for Moisture, Ash, and

159 Organic Matter of Peat and Organic Soils) was used to determine the content of organic

160 matter in soil. The soil was first dried in an oven at $105^{\circ} \mathrm{C}$ for $24 \mathrm{~h}$. The dry soil was

161 weighed and then combusted at $440{ }^{\circ} \mathrm{C}$ for $24 \mathrm{~h}$. The loss in mass was assumed to be due

162 entirely to oxidation of organic matter. Three replicates were prepared for each type of 
163 soil. The average organic matter contents were $11.87 \% \pm 0.56 \%$ for loamy sand and

$1642.21 \% \pm 0.04 \%$ (average \pm standard error, $\mathrm{n}=3$ ) for silty loam.

\section{Experimental Setup}

\section{Soil preparation}

167 The growing pots were established by adding $150 \mathrm{~g}$ of dry soil to a plastic

168 container ( $266 \mathrm{~mL}$ total volume). $\mathrm{CeO}_{2} \mathrm{NPs}$ dispersion and deionized water were added

169 to the container in different proportions so that the soil was saturated to $100 \%$ of field

170 capacity and at the same time reached the targeted concentration of $\mathrm{CeO}_{2} \mathrm{NPs}$

171 homogeneously. Four concentrations of $\mathrm{CeO}_{2} \mathrm{NPs}$ were prepared for each type of soil:

172 control (no treatment), 100, 500 and $1000 \mathrm{mg} \mathrm{Ce} / \mathrm{kg}$ dry soil. The concentrations were

173 chosen based on the most frequently used concentrations in the literature for the fate and

174 phytotoxicity study of metal oxide nanoparticles to terrestrial plants (Holden et al., 2014).

175 Each treatment had six replicates. Altogether, 24 such containers were prepared for each

176 soil. The soil were incubated for one day before radish seeds were sowed.

177 Seed germination and growth conditions

178 Radish seeds [Cherriette (F1)] were purchased from Johnny's Selected Seeds

179 (Winslow, ME). Three seeds were placed approximately $15 \mathrm{~mm}$ beneath the soil surface

180 in each container with soils containing different concentrations of $\mathrm{CeO}_{2} \mathrm{NPs}$. After

181 germination, each container was thinned to one seedling.

182 Plants were irrigated with quarter strength Hoagland's solution to a constant mass

183 (230 g after irrigation) daily from Day 6 to Day 15 after sowing. The soil was then

184 irrigated to the same constant mass with half strength Hoagland's solution until harvest

185 (Day 31). Plants were incubated on a growth cart with a $16 \mathrm{~h}$ photoperiod at $28{ }^{\circ} \mathrm{C}$ and 
186 ambient humidity. The growth cart was equipped with four T5 fluorescent bulbs,

187 providing a light intensity of approximately $104 \mathrm{umol} \mathrm{m}^{-2} \mathrm{~s}^{-1}$ at the height of plant shoots.

188 Relative chlorophyll content was measured with a SPAD 502 Plus Chlorophyll Meter at

189 Day 26 and was expressed as a percentage of the control plants.

190 Cerium fractionation in soil

191 At harvest, plants were gently removed from the soil for further analysis (details

192 described below). The soil was homogenized and then three samples were randomly

193 collected from three containers in each treatment and extracted with the modified BCR

194 method to determine the fractionation of $\mathrm{CeO}_{2}$ NPs in soil. The sample was first

195 extracted with $20 \mathrm{~mL}$ of $0.11 \mathrm{M}$ acetic acid solution by shaking at $250 \mathrm{rpm}$ for 16 hours

196 at $22 \pm 5^{\circ} \mathrm{C}$ and centrifuged at $3,000 \mathrm{~g}$ for 20 minutes to obtain the exchangeable fraction

197 (F1). The residue was then resuspended and extracted by $20 \mathrm{~mL}$ of $0.5 \mathrm{M}$ hydroxylamine

198 hydrochloride solution at $\mathrm{pH} 1.5$ and shaken at $250 \mathrm{rpm}$ for 16 hours at $22 \pm 5^{\circ} \mathrm{C}$. The

199 mixture was centrifuged similarly as described above to obtain the reducible fraction (F2).

200 The residue was then resuspended and mixed with $30 \% \mathrm{H}_{2} \mathrm{O}_{2}$ and shaken at $250 \mathrm{rpm}$ for 1

201 hour at room temperature, followed by another hour of shaking at $250 \mathrm{rpm}$ at $85 \pm 2{ }^{\circ} \mathrm{C}$

202 with a closed cap. The volume of the mixture was reduced to less than $1.5 \mathrm{~mL}$ by further

203 heating at the same temperature without cap. Following the volume reduction, an aliquot

204 of $5 \mathrm{~mL}$ of $30 \% \mathrm{w} / \mathrm{v} \mathrm{H}_{2} \mathrm{O}_{2}$ was added and the heating process was repeated until the

205 volume was reduced to about $0.5 \mathrm{~mL}$. Afterwards, $25 \mathrm{~mL}$ of $1 \mathrm{M}$ ammonium acetate

206 solution at $\mathrm{pH} 2$ was mixed with the residue for 16 hours at $22 \pm 5^{\circ} \mathrm{C}$ and the mixture was

207 centrifuged at 3,000 g for 20 minutes to extract the oxidizable fraction (F3). The residue

208 fraction $(\mathrm{F} 4)$ was extracted by aqua regia following the ISO 11466 protocol; $4.5 \mathrm{~mL}$ of 
$\mathrm{HCl}(12.0 \mathrm{M})$ and $1.5 \mathrm{~mL}$ of $\mathrm{HNO}_{3}(15.8 \mathrm{M})$ was added drop-wise to $0.5 \mathrm{~g}$ of residue

210 from the third fraction. The mixture was left at room temperature for 16 hours and then

211 was transferred to a $50 \mathrm{~mL}$ reaction vessel connected to a reflux condenser. The reaction

212 vessel was heated until reflux conditions were reached and was continuously heated for 2

213 hours (the condensation zone is lower than $1 / 3$ of the height of the condenser). The

214 condenser was further rinsed with $10 \mathrm{~mL} \mathrm{HNO}_{3}(0.5 \mathrm{M})$ and the rinsing solution and

215 additional $\mathrm{HNO}_{3}(0.5 \mathrm{M})$ were collected and added to the reaction vessel until they

216 reached the $50 \mathrm{~mL}$ scale line. The supernatant solution of each fraction was analyzed for

217 Ce by an Agilent 7500ce Inductively Coupled Plasma Mass Spectrometry (ICP-MS,

218 Santa Clara, CA).

219 Scanning electron microscope characterization of cerium in soil

220 To determine the physicochemical characteristics of $\mathrm{CeO}_{2} \mathrm{NPs}$ in soil, air dried

221 control and $1000 \mathrm{mg} / \mathrm{kg}$ treated loamy sand and silty loam soils were fixed on a double-

222 sided adhesive tape, which was adhered to the specimen holder, and were analyzed using

223 FEI Quanta FEG450 scanning electron microscope (SEM) equipped with an Energy

224 Dispersive X-ray Spectroscopy (EDS). The SEM imaging of soil samples was performed

225 by applying accelerating voltages of $10 \mathrm{kV}$. The concentration of $1000 \mathrm{mg} / \mathrm{kg} \mathrm{CeO}_{2} \mathrm{NPs}$,

226 the highest concentration used in this study, was selected to ensure the detectability of

$227 \mathrm{CeO}_{2}$ NPs by SEM.

228 Plant uptake and accumulation of cerium

229 After plants were carefully removed from the soil, they were separated into

230 shoots, storage root (the edible radish bulb) and fine roots. The separated tissues were

231 rinsed with DI water to remove all adhering soil particles and dried in an oven at $105^{\circ} \mathrm{C}$ 
232 for 30 minutes, then at $75{ }^{\circ} \mathrm{C}$ for seven days prior to dry weight determination. After

233 drying in the oven, three replicates in each treatment were randomly chosen. The dried

234 shoot, storage root, and fine root tissues were ground into fine powders and digested in 4

$235 \mathrm{~mL}$ of $70 \%(\mathrm{v} / \mathrm{v})$ nitric acid. The nitric acid digest was heated at $95{ }^{\circ} \mathrm{C}$ for 20 minutes and

236 then at $45^{\circ} \mathrm{C}$ for 4 minutes. The cycle was repeated until all the dry tissues was

237 dissolved. Afterwards, $2 \mathrm{~mL}$ of $\mathrm{H}_{2} \mathrm{O}_{2}$ was added to the mixture. The mixture was heated

238 using the same temperature cycle until the solution was clear. The digest solutions of

239 storage roots and shoots were then analyzed by ICP-MS. The digest solution of fine roots

240 was analyzed by a Thermal Scientific iCAP 6500 Inductively Coupled Plasma Optical

241 Emission Spectrometry (ICP-OES) due to the high cerium concentration in the fine root

242 tissue.

\section{Distribution of cerium in radish shoots and storage roots}

244 Three replicates from the control and $500 \mathrm{mg} / \mathrm{kg}$ treatment group grown in both

245 soils were used as representatives to illustrate the cerium localization in the radish storage

246 roots and shoots. The whole storage root was divided into three layers with a precision

247 knife: the periderm (Peri), the intermediate layer (L1), and the inner layer (L2). The

248 thicknesses of the periderm and the intermediate layer were approximately $1 \mathrm{~mm}$ and 5

249 mm respectively (Figure 2). Each shoot was divided into two sections: the edges (S1) and

250 the main leaf area (S2). The width of the edges was about 5- $7 \mathrm{~mm}$ (Figure 2). The

251 subsections of the storage roots and shoots were oven dried and digested as described

252 above for the whole tissues. The digest solutions were analyzed by ICP-MS.

\section{Data analysis}

254 The statistical analysis of experimental data was performed by means of one-way 
255 and two-way ANOVA using IBM SPSS Statistics 20.0. The Duncan test was conducted

256 for post hoc comparisons. A student $t$ test was conducted to determine the significance of

257 soil impact at the same concentration. Statistical significance was accepted when $\mathrm{p}<0.05$.

258 Results

259 Plant physiological status

260 The dry biomass of storage roots and shoots are shown in Supplementary Figure

261 1. For both soils, treatment with 100 and $500 \mathrm{mg} / \mathrm{kg} \mathrm{CeO} 2$ NPs did not cause any

262 significant differences between the treated plants and their controls. Exposure to $1000 \mathrm{mg}$

$263 / \mathrm{kg} \mathrm{CeO}_{2} \mathrm{NPs}$ resulted in significantly greater dry biomass of the storage root than all

264 other treated and control plants in loamy sand. The same treatment, however, led to

265 significantly lower dry biomass of storage roots than that of $500 \mathrm{mg} / \mathrm{kg}$ treated radishes in

266 silty loam. When the biomass of radishes grown in two soils at the same concentration

267 was compared, the storage roots of control, $100 \mathrm{mg} / \mathrm{kg}$, and $500 \mathrm{mg} / \mathrm{kg} \mathrm{CeO} \mathrm{NPs}_{2}$ treated

268 radishes were significantly greater in silty loam than in loamy sand. At the highest

269 concentration, the difference of the storage root biomass between the two soils was not

270 significant.

271 In contrast to the storage root biomass, the shoot biomass was not affected by

$272 \mathrm{CeO}_{2} \mathrm{NPs}$ exposure for either soil. However, significant differences were noticed

273 between the soil types at control and $100 \mathrm{mg} / \mathrm{kg}$ treatment. Radishes grown in silty loam

274 soil from the two concentration groups had significantly higher shoot biomass than the

275 plants grown in loamy sand. The relative chlorophyll contents, expressed as percentages

276 of controls, are shown in Supplementary Table 2. No significant differences were

277 observed across the treatments. 


\section{Cerium fractionation in soil}

279 The percentage of each fraction in the two soils is illustrated in stacked columns

280 in Figure 3. F4 was the dominant fraction of $\mathrm{CeO}_{2} \mathrm{NPs}$ in both soils, and the percentage

281 was invariably higher in silty loam (60.8-78.2\%) than in loamy sand (58.6-70.5\%) at the

282 same concentration. F1 was the smallest fraction and accounted for less than $0.11 \%$ in

283 loamy sand and $0.22 \%$ in silty loam. While the relative percentage of F2 was comparable

284 between the two soils, the loamy sand always contained higher oxidizable fraction (F3)

285 than silty loam at the same concentration (15.8-17.8\% for loamy sand vs. $9.07-11.8 \%$ for

286 silty loam). The distribution of $\mathrm{CeO}_{2} \mathrm{NPs}$ among these four fractions changed with

287 concentration. In general, with the increase of concentration, the percentage of F1 and F2

288 decreased while the percentage of F4 increased in both soils. The percentage of F3 was

289 relatively stable across the concentration ranges employed in this study.

290 The actual concentrations of each individual fraction are presented in

291 Supplementary Figure 2. As the most abundant rare earth element on the earth's crust,

292 both soils contained high background concentration of cerium. The total background

293 cerium was $52.5 \pm 1.87 \mathrm{mg} / \mathrm{kg}$ dry soil in the loamy sand and $77.2 \pm 5.25 \mathrm{mg} / \mathrm{kg}$ dry soil

294 in the silty loam. Due to the high background concentrations of cerium, the fractionation

295 of dosed $\mathrm{CeO}_{2}$ was calculated by subtracting the cerium concentration in each individual

296 fraction of the control soil from the concentrations in the corresponding fractions of the

297 treated soil. The results are presented in Figure 4. Both the dosing concentration and soil

298 characteristics were significant factors affecting the fractionation of $\mathrm{CeO}_{2} \mathrm{NPs}$ in soil

299 according to the two-way ANOVA analysis. In general, the silty loam contained higher

300 F1 than the loamy sand and the difference was significant for $500 \mathrm{mg} / \mathrm{kg}$ treatment 
301 (Figure 4a). The silty loam contained significantly lower F2 and F3 than the loamy sand

302 in 500 and $1000 \mathrm{mg} / \mathrm{kg}$ treatment. The silty loam had significantly higher F4 than the

303 loamy sand in $100 \mathrm{mg} / \mathrm{kg}$ but the differences in F4 were not significant in higher

304 concentrations (Figure 4d). It has been reported that $\mathrm{CeO}_{2} \mathrm{NPs}$ cannot be fully dissolved

305 in aqua regia (Antisari et al., 2011). Therefore, it is likely that some cerium residues

306 remained in the soil and was not included in the four fractions reported here.

307 To further probe the differences of $\mathrm{CeO}_{2} \mathrm{NPs}$ behaviors in the two soils, SEM

308 analysis was conducted. The SEM images shown in Figure 5 were acquired with samples

309 from control and $1000 \mathrm{mg} / \mathrm{kg}$ treatment. EDS analysis was conducted in the selected area

310 (red frames in the images) to detect the component elements. The main components of

311 the two soils were silica and oxygen. In control samples from both soil types, no cerium

312 was detected by the EDS even though ICP-MS analysis showed that both soils contained

313 high background cerium. However, in $1000 \mathrm{mg} / \mathrm{kg}$ treatment, the cerium weight

314 percentages were $7.23 \%$ and $8.05 \%$ in loamy sand and silty loam, respectively. The

315 cerium signals in both soil indicate that the $\mathrm{CeO}_{2} \mathrm{NPs}$ were mainly attached to the edge

316 of soil particles. Individual particle aggregates could be seen in the treated loamy sand,

317 but not in the silty loam soil.

318 Cerium uptake and accumulation

319 Cerium was detected in all plant tissues even though the total accumulation of

320 cerium in plant biomass was relatively small compared with the total cerium added to the

321 system. The concentrations and the total mass of cerium in different plant tissues are

322 presented in Supplementary Figure 3. Due to the high background cerium concentration

323 in control plants, the accumulation of the dosed cerium in different plant tissues was 
324 calculated by subtracting the cerium concentration in different plant tissues of the control

325 plants from the corresponding tissues of treated ones and the results are presented in

326 Figure 6. Even though the accumulation of cerium in all tissues increased with

327 increasing concentration in general, a dose response relationship was not apparent, 328 especially for the shoot tissues.

329 The comparison of cerium accumulation by plants grown in two soil types

330 indicated that the radish fine roots and storage root from the loamy sand usually

331 possessed higher cerium concentration than the same tissues collected from the silty

332 loam. Interestingly, the cerium concentration in the shoot showed opposite trend between

333 these two soils. However, none of these differences were significant except for the

334 cerium in the fine roots from $100 \mathrm{mg} / \mathrm{kg}$ treatment.

\section{Cerium localization in radish storage roots and shoots}

336 The cerium concentrations in different sections of radish storage roots and shoots

337 are shown in Table 1. The average cerium concentration in the periderm (Peri) of radish

338 storage roots from $500 \mathrm{mg} / \mathrm{kg}$ was more than ten times higher than that of control in both

339 soils. However, large variations were observed between replicates from the same

340 treatment group. Cerium concentrations in the intermediate layer (L1) and the inner layer

341 were comparable to the control plants in both soils. In radish leaves, the cerium

342 concentrations in the edge section (S1) of treated and control plants were similar for both

343 soils. However, the average cerium concentration in the main leaf area (S2) was

344 significantly higher (almost three times) from $500 \mathrm{mg} / \mathrm{kg}$ treated radish than from control

345 plants in the silty loam. No difference was observed for the main leaf area in control

346 plants and $500 \mathrm{mg} / \mathrm{kg}$ treated plants in loamy sand. 


\section{Discussion}

349 Although plant uptake of $\mathrm{CeO}_{2} \mathrm{NPs}$ from soil has been observed previously (Rico

350 et al., 2013; López-Moreno et al., 2010; Wang et al., 2012; Wang et al., 2013; Zhang et

351 al., 2011), the influence of soil properties on $\mathrm{CeO}_{2} \mathrm{NPs}$ bioavailability has not been

352 examined. However, once cerium enters soil through wastewater irrigation or biosolid

353 amendment, particle bioavailability may depend heavily on the physical and chemical

354 properties of soil, as noted for other elements (Ernst, 1996). The results of this study

355 confirmed that the accumulation and translocation of $\mathrm{CeO}_{2} \mathrm{NPs}$ in plant tissues depend

356 heavily on soil type due to the impact of soil on $\mathrm{CeO}_{2} \mathrm{NPs}$ fractionation.

357 Even though $\mathrm{CeO}_{2} \mathrm{NPs}$ are generally perceived as stable in the environment,

358 dissolution does occur and Cornelis et al. (Cornelis et al., 2011) reported that about $0.25 \%$

359 of total $\mathrm{CeO}_{2}$ NPs in soil was released as ions at $\mathrm{pH} 7$ and 9 in soil. The presence of

360 chelating agents in the soil may further enhance the dissolution by forming complexes

361 with $\mathrm{Ce}^{3+}$ on the surface of $\mathrm{CeO}_{2} \mathrm{NPs}$ (Schwabe et al., 2014). F1 was considered to

362 include both the dissolved ions and dissolved nanoparticles. Due to the low solubility of

$363 \mathrm{CeO}_{2}$ NPs and possibly the rapid adsorption of dissolved ions to the solid phase, F1

364 represented a negligible fraction in both soils in this study even though the concentration

365 of $\mathrm{F} 1$ increased with concentrations $\left(<0.16 \%\right.$ for the dosed $\left.\mathrm{CeO}_{2} \mathrm{NPs}\right)$. Water soluble

366 cerium at low concentration is generally not considered as toxic and is sometimes used as

367 fertilizer (Hu et al., 2002). The F1 in silty loam was invariably higher than that in loamy

368 sand at the same concentration. Therefore, the differences of F1 may partially explain the

369 generally higher dry biomass of radish storage roots and shoots in silty loam than in 

loamy sand (Supplementary Figure 1).

$371 \quad$ Fe-Mn oxides, considered as secondary minerals, exist primarily in the clay

372 (Allen and Hajek, 1989; Fieldes and Swindale, 1954; Post, 1999). Therefore, the higher

373 reducible $\mathrm{CeO}_{2}(\mathrm{~F} 2)$ in silty loam with higher clay content may be expected. Interestingly,

374 the expectation was only consistent with the observations at lower concentrations $(<100$

$375 \mathrm{mg} / \mathrm{kg}$ ). At higher concentrations (500 and $1000 \mathrm{mg} / \mathrm{kg}$ ), the opposite trend was observed.

376 Two processes may have contributed to the seemingly inconsistent observations of $\mathrm{CeO}_{2}$

377 NPs fractionation in these two soils. Firstly, the $\mathrm{CeO}_{2}$ NPs used in this study were

378 positively charged, as indicated by their surface zeta potential. At neutral $\mathrm{pH}$, the surface

379 charges of quartz and feldspars, which are the main components of sand and silt, are

380 negative (Jada et al., 2006; Yin and Drelich, 2008). Previous research showed that

381 electrons can accumulate at the edges of clay particles (Bolland et al., 1976). Therefore,

$382 \mathrm{CeO}_{2} \mathrm{NPs}$ can be electrostatically attracted to the electrons on clay edges and precipitate

383 (Cornelis et al., 2011). The strong affinity between $\mathrm{CeO}_{2}$ NPs and some soil particles is

384 supported by the SEM images (Figure 5). The electrostatic forces present may therefore

385 restrain the direct contact of $\mathrm{CeO}_{2} \mathrm{NPs}$ with Fe-Mn oxides in the clay. Secondly, the

386 extractant (hydroxylamine hydrochloride) used to recover F2 may lead to higher cerium

387 concentration in loamy sand due to its high reducing capacity. It has been reported that

388 hydroxylamine hydrochloride can reduce $\mathrm{Ce}^{4+}$ in $\mathrm{CeO}_{2}$ to $\mathrm{Ce}^{3+}$ ions $\left(2 \mathrm{CeO}_{2}+\mathrm{NH}_{2} \mathrm{OH}+\right.$

$389 \mathrm{NH}_{3} \mathrm{OH}^{+}+2 \mathrm{H}_{2} \mathrm{O} \rightarrow 2 \mathrm{Ce}(\mathrm{OH})_{3}+\mathrm{NO}_{2}^{-}+\mathrm{NH}_{4}^{+}+\mathrm{H}^{+} . \mathrm{E}^{\mathrm{o}}=0.232 \mathrm{~V}$ ) (Tamilmani et al.,

390 2003). The reaction might be stronger between the extractant and the more mobile $\mathrm{CeO}_{2}$

391 NPs in the loamy sand, leading to high measurement of F2 in the loamy sand than in silty

392 loam. This hypothesis needs further evaluation. Different hydrodynamic sizes of $\mathrm{CeO}_{2}$ 
393 NPs at different concentrations might also affect their precipitation and association with

394 different fractions of soil particles. Future studies should aim to characterize ENPs in the

395 actual environment in addition to the characterization of primary particles.

396 The oxidizable fraction $(\mathrm{F} 3)$ of $\mathrm{CeO}_{2}$ is believed to be associated with organic

397 matter in soil. The higher organic matter content in loamy sand soil is consistent with the

398 generally higher F3 in this soil than in the silty loam. Natural organic matter can enhance

399 the mobility of NPs in porous media by increasing charge and steric stabilization (Lin et

400 al., 2010). Zhao et al. (Zhao et al., 2012) studied the uptake of $\mathrm{CeO}_{2} \mathrm{NPs}$ by corn grown

401 in soils and concluded that organic matter improved the mobility and bioavailability of

$402 \mathrm{CeO}_{2} \mathrm{NPs}$ to corn, resulting in higher accumulation of $\mathrm{Ce}$ in corn roots. The consistently

403 higher cerium concentration in the fine roots and storage roots of radish grown in loamy

404 sand was consistent with the relative organic matter contents in these two soils. These

405 findings support the theory that natural organic matter plays an important role in

406 regulating the mobility and bioavailability of engineered nanoparticles to plants (Antisari

407 et al., 2011).

408 One intriguing observation of this study was the disparity of roots and shoots with

409 regard to $\mathrm{CeO}_{2} \mathrm{NPs}$ accumulation from different soils. As described above, the radish

410 storage roots and fine roots generally contained higher cerium concentration in loamy

411 sand. However, the concentrations of cerium in shoot tissues followed the opposite trend

412 between the soils. It is postulated that the low translocation of cerium in the loamy sand

413 is associated with the low F1 in that soil. Previous research suggested that engineered

414 nanoparticles in plant roots are translocated up through the xylem tissues along with

415 water (Allen and Hajek, 1989), which makes the water soluble fraction more readily 
416 transferred to the shoot tissues. A recent study also demonstrated that negatively charged

417 humus colloids in soil could chelate with positively charged $\mathrm{CeO}_{2} \mathrm{NPs}$ and reduce their

418 mobility and bioavailability in soil (Majumdar et al., 2015). Consequently, the upward

419 transport of $\mathrm{CeO}_{2} \mathrm{NPs}$ from root to shoot will be limited in soil grown plants and the

420 extent of transport may depend significantly on the amount of water soluble fraction. Our

421 results agreed with the observation of the low root to shoot translocation of $\mathrm{CeO}_{2} \mathrm{NPs}$ in

422 organic matter enriched soil, but contradicted a previous study which indicated that

423 organic matter enriched soil facilitated the uptake and translocation of $\mathrm{CeO}_{2} \mathrm{NPs}$ by corn

424 (Zhao et al., 2012). The discrepancies may derive from the use of different $\mathrm{CeO}_{2} \mathrm{NPs}$ and

425 different plant species and require further investigation.

426 Following the uptake of cerium, we further evaluated whether the different soil

427 fractionation would affect the distribution of cerium in different plant tissues. Consistent

428 with our previous investigation (Zhang et al., 2015), cerium was predominantly

429 accumulated in the pigmented periderm of radish storage roots for both soils (Table 1).

430 Another recent study on the interactions between $\mathrm{CeO}_{2}$ NPs and carrot (Daucus carota L.)

431 also reported that the accumulation of cerium element principally in the taproot peel and

432 the shoots, with significantly lower cerium concentration in the edible flesh (Ebbs et al.,

433 2015). Notably, even though the average concentration in the periderm was ten times

434 higher in the $500 \mathrm{mg} / \mathrm{kg}$ treated radish than the control radish in this study, high

435 variability between the replicates of treated radish was noticed $(51.7-217 \mathrm{mg} / \mathrm{kg}$ dry

436 tissue for loamy sand and $45.5-236 \mathrm{mg} / \mathrm{kg}$ dry tissue for silty loam). It is likely that the

437 high variability was due to the unequal adsorption of $\mathrm{CeO}_{2} \mathrm{NPs}$ on the skin surface of the

438 storage root and the rinsing process during harvest. The similar cerium concentration in 
439 the intermediate and inner layers of the treated and control plants suggested that cerium

440 accumulation in the flesh is limited. Altogether, the results indicate that a primary

441 pathway for cerium accumulation in radish storage roots was physical adsorption on the

442 surface and radial diffusion toward the center which is minimal in this study.

443 Interestingly, the cerium concentration in S2 section of the shoot tissue grown in silty

444 loam was three times higher than their corresponding controls, but such difference was

445 not observed in the sandy loam. Our finding is consistent with the higher shoot

446 concentration in $\mathrm{CeO}_{2}$ NPs treated radish in silty loam and substantiates our earlier

447 contention that F1 was more readily translocated from radish roots to shoots. A previous

448 study indicated that the cerium taken up from roots is transported to leaves through leaf

449 vein vasculature with the transpiration stream (Zhao et al., 2013) and our results appeared

450 to support that conclusion. It is yet to know, however, whether the translocated cerium

451 was in the $\mathrm{CeO}_{2}$ NPs form or other chemical forms.

452 In summary, soil characteristics were shown to be an important factor affecting

453 the soil fractionation and subsequent bioavailability of $\mathrm{CeO}_{2}$ NPs to plants. The

454 accumulation of cerium in radish belowground tissues correlated well with the sum of the

455 first three fractions, suggesting that these fractions were bioavailable to plant roots.

456 However, only the exchangeable fraction correlated well with the element amounts

457 shown to transport from roots to shoots. In addition to their bioavailability, the

458 distribution of cerium in different plant tissues was also affected by the physicochemical

459 properties soils, indicating that the specific soil properties must be an important

460 consideration in the assessment of the fate and transport of engineered nanoparticles in

461 the environment. 
464 The authors acknowledge the financial support of the USDA-AFRI (\#2012-67005-19585)

465 and USDA-AFRI (\#2011-67006-30181). Xingmao Ma also acknowledges the Startup

466 Support from Texas A\&M University.

\section{Author's Contribution}

469 X.M conceived and supervised the experiment. W. Z and Q. W conducted the experiment 470 and $\mathrm{W}$. $\mathrm{Z}$ also prepared the first draft of the manuscript. C. M conducted ICP-MS

471 analysis. J.W., P. S., S. E, and X. M contributed to data analysis and interpretation and X.

$472 \mathrm{M}$ also contributed to the writing of the manuscript. All authors read and approved the 473 final version of the manuscript.

474

475

476

477

478

479

480

481

482

483

484

485

486

487

488

489

490

491

492

493

494

495

496
Reference 
497

498

499

500

501

502

503

504

505

506

507

508

509

510

511

512

513

514

515

516

517

518

519

520

521

522

523

524

525

526

527

528

529

530

531

532

533

534

535

536

537

538

539

540

541

542

Allen B.L., Hajek B.F., 1989. Mineral occurrence in soil environments. Minerals in soil environments. 2, 199-278.

Antisari L.V., Carbone S., Fabrizi A., Gatti A., Vianello G., 2011. Response of soil microbial biomass to $\mathrm{CeO} 2$ nanoparticles. EQA-International Journal of Environmental Quality. 7, 1-16.

Backes C.A., McLaren R.G., Rate A.W., Swift R.S., 1995. Kinetics of cadmium and cobalt desorption from iron and manganese oxides. Soil Science Society of America Journal. 59, 778-785.

Bolland M.D.A., Posner A., Quirk J., 1976. Surface charge on kaolinites in aqueous suspension. Soil Research. 14, 197-216.

Bouyoucos G.J., 1962. Hydrometer method improved for making particle size analyses of soils. Agronomy Journal. 54, 464-465.

Cornelis G., Ryan B., McLaughlin M.J., Kirby J.K., Beak D., Chittleborough D., 2011. Solubility and batch retention of $\mathrm{CeO} 2$ nanoparticles in soils. Environmental science \& technology. 45, 2777-2782.

Corral-Diaz B., Peralta-Videa J.R., Alvarez-Parrilla E., Rodrigo-García J., Morales M.I., Osuna-Avila P., Niu G., Hernandez-Viezcas J.A., Gardea-Torresdey J.L., 2014. Cerium oxide nanoparticles alter the antioxidant capacity but do not impact tuber ionome in Raphanus sativus (L). Plant Physiol Biochem. 84, 277-285.

Ebbs S.D., Bradfield S.J., Kumar P., White J.C., Musante C., Ma X., 2015. Accumulation of zinc, copper, or cerium in carrot (Daucus carota) exposed to metal oxide nanoparticles and metal ions. Environmental Science: Nano. doi:10.1039/C5EN00161G.

Ernst W., 1996. Bioavailability of heavy metals and decontamination of soils by plants. Applied geochemistry. 11, 163-167.

Fieldes M., Swindale L., 1954. Chemical weathering of silicates in soil formation. New Zealand J Sci Tech. 36, 140-154.

Gleyzes C., Tellier S., Astruc M., 2002. Fractionation studies of trace elements in contaminated soils and sediments: a review of sequential extraction procedures. TrAC Trends in Analytical Chemistry. 21, 451-467.

Gui X., Zhang Z., Liu S., Ma Y., Zhang P., He X., Li Y., Zhang J., Li H., Rui Y., 2015. Fate and phytotoxicity of $\mathrm{CeO} 2$ nanoparticles on lettuce cultured in the potting soil environment. PloS one. 10, e0134261.

Holden P.A., Klaessig F., Turco R.F., Priester J.H., Rico C.M., Avila-Arias H., Mortimer M., Pacpaco K., Gardea-Torresdey J.L., 2014. Evaluation of exposure concentrations used in assessing manufactured nanomaterial environmental hazards: are they relevant? Environmental science \& technology. 48, 1054110551.

Hu X., Ding Z., Chen Y., Wang X., Dai L., 2002. Bioaccumulation of lanthanum and cerium and their effects on the growth of wheat (Triticum aestivum L.) seedlings. Chemosphere. 48, 621-629.

Jada A., Ait Akbour R., Douch J., 2006. Surface charge and adsorption from water onto quartz sand of humic acid. Chemosphere. 64, 1287-1295.

Li J., Lu Y., Shim H., Deng X., Lian J., Jia Z., Li J., 2010. Use of the BCR sequential extraction procedure for the study of metal availability to plants. Journal of Environmental Monitoring. 12, 466-471. 
Lin D., Tian X., Wu F., Xing B., 2010. Fate and transport of engineered nanomaterials in the environment. Journal of environmental quality. 39, 1896-1908.

López-Moreno M.L., de la Rosa G., Hernández-Viezcas J.Á., Castillo-Michel H., Botez C.E., Peralta-Videa J.R., Gardea-Torresdey J.L., 2010. Evidence of the differential biotransformation and genotoxicity of $\mathrm{ZnO}$ and $\mathrm{CeO} 2$ nanoparticles on soybean (Glycine max) plants. Environmental science \& technology. 44, 73157320.

Ma Y., Zhang P., Zhang Z., He X., Li Y., Zhang J., Zheng L., Chu S., Yang K., Zhao Y., 2015. Origin of the different phytotoxicity and biotransformation of cerium and lanthanum oxide nanoparticles in cucumber. Nanotoxicology. 9, 262-270.

Majumdar S., Almeida I.C., Arigi E.A., Choi H., VerBerkmoes N.C., Trujillo-Reyes J., Flores-Margez J.P., White J.C., Peralta-Videa J.R., Gardea-Torresdey J.L., 2015. Environmental effects of nanoceria on seed production of common bean (Phaseolus vulgaris): a proteomic analysis. Environmental science \& technology. 49, 13283-13293.

Masui T., Hirai H., Imanaka N., Adachi G., Sakata T., Mori H., 2002. Synthesis of cerium oxide nanoparticles by hydrothermal crystallization with citric acid. Journal of materials science letters. 21, 489-491.

Naumov A., 2008. Review of the world market of rare-earth metals. Russian Journal of Non-Ferrous Metals. 49, 14-22.

Pelletier D.A., Suresh A.K., Holton G.A., McKeown C.K., Wang W., Gu B., Mortensen N.P., Allison D.P., Joy D.C., Allison M.R., 2010. Effects of engineered cerium oxide nanoparticles on bacterial growth and viability. Applied and environmental microbiology. 76, 7981-7989.

Post J.E., 1999. Manganese oxide minerals: Crystal structures and economic and environmental significance. Proceedings of the National Academy of Sciences. 96, 3447-3454.

Rao C.R.M., Sahuquillo A., Lopez-Sanchez J.F., 2010. Comparison of single and sequential extraction procedures for the study of rare earth elements remobilisation in different types of soils. Analytica chimica acta. 662, 128-136.

Rauret G., Lopez-Sanchez J., Sahuquillo A., Rubio R., Davidson C., Ure A., Quevauviller P., 1999. Improvement of the BCR three step sequential extraction procedure prior to the certification of new sediment and soil reference materials. Journal of Environmental Monitoring. 1, 57-61.

Rico C.M., Hong J., Morales M.I., Zhao L., Barrios A.C., Zhang J.-Y., Peralta-Videa J.R., Gardea-Torresdey J.L., 2013. Effect of cerium oxide nanoparticles on rice: a study involving the antioxidant defense system and in vivo fluorescence imaging. Environmental science \& technology. 47, 5635-5642.

Rosenkranz P., Fernández-Cruz M., Conde E., Ramírez-Fernández M., Flores J., Fernández M., Navas J., 2012. Effects of cerium oxide nanoparticles to fish and mammalian cell lines: An assessment of cytotoxicity and methodology. Toxicology in Vitro. 26, 888-896.

Rui Y., Zhang P., Zhang Y., Ma Y., He X., Gui X., Li Y., Zhang J., Zheng L., Chu S., 2015. Transformation of ceria nanoparticles in cucumber plants is influenced by phosphate. Environmental Pollution. 198, 8-14. 
Sahuquillo A., Rigol A., Rauret G., 2003. Overview of the use of leaching/extraction tests for risk assessment of trace metals in contaminated soils and sediments. TrAC Trends in Analytical Chemistry. 22, 152-159.

Schwabe F., Schulin R., Rupper P., Rotzetter A., Stark W., Nowack B., 2014. Dissolution and transformation of cerium oxide nanoparticles in plant growth media. Journal of nanoparticle research. 16, 1-11.

Schwabe F., Tanner S., Schulin R., Rotzetter A., Stark W., von Quadt A., Nowack B., 2015. Dissolved cerium contributes to uptake of $\mathrm{Ce}$ in the presence of differently sized $\mathrm{CeO}$ 2-nanoparticles by three crop plants. Metallomics. 7, 466-477.

Tamilmani S., Shan J., Huang W., Raghavan S., Small R., Shang C., Scott B., 2003. Interaction between ceria and hydroxylamine. MRS Proceedings. 767, F3. 3.

Ure A.M., Quevauvillerb P., Muntauc H., Griepinkb B., 1993. Speciation of heavymetals in soils and sediments - an account of the improvement and harmonization of extraction techniques undertaken under the auspices of the BCR of the Commission of the European Communities. International Journal of Environmental Analytical Chemistry. 51, 135-151.

Wang Q., Ebbs S.D., Chen Y., Ma X., 2013. Trans-generational impact of cerium oxide nanoparticles on tomato plants. Metallomics. 5, 753-759.

Wang Q., Ma X., Zhang W., Pei H., Chen Y., 2012. The impact of cerium oxide nanoparticles on tomato (Solanum lycopersicum L.) and its implications for food safety. Metallomics. 4, 1105-1112.

Yin X., Drelich J., 2008. Surface charge microscopy: Novel technique for mapping charge-mosaic surfaces in electrolyte solutions. Langmuir. 24, 8013-8020.

Zhang F., Chan S.-W., Spanier J.E., Apak E., Jin Q., Robinson R.D., Herman I.P., 2002. Cerium oxide nanoparticles: size-selective formation and structure analysis. Applied physics letters. 80, 127-129.

Zhang W., Ebbs S.D., Musante C., White J.C., Gao C., Ma X., 2015. Uptake and accumulation of bulk and nano-sized cerium oxide particles and ionic cerium by radish (Raphanus sativus L.). Journal of agricultural and food chemistry. 63, 382390.

Zhang Z., He X., Zhang H., Ma Y., Zhang P., Ding Y., Zhao Y., 2011. Uptake and distribution of ceria nanoparticles in cucumber plants. Metallomics. 3, 816-822.

Zhao L., Peralta-Videa J.R., Varela-Ramirez A., Castillo-Michel H., Li C., Zhang J., Aguilera R.J., Keller A.A., Gardea-Torresdey J.L., 2012. Effect of surface coating and organic matter on the uptake of $\mathrm{CeO} 2 \mathrm{NPs}$ by corn plants grown in soil: insight into the uptake mechanism. Journal of hazardous materials. 225, 131-138.

Zhao L., Sun Y., Hernandez-Viezcas J.A., Hong J., Majumdar S., Niu G., Duarte-Gardea M., Peralta-Videa J.R., Gardea-Torresdey J.L., 2015. Monitoring the environmental effects of $\mathrm{CeO} 2$ and $\mathrm{ZnO}$ nanoparticles through the life cycle of corn (Zea mays) plants and in situ $\mu$-XRF mapping of nutrients in kernels. Environmental Science \& Technology. 49, 2921-2928.

Zhao L., Sun Y., Hernandez-Viezcas J.A., Servin A.D., Hong J., Niu G., Peralta-Videa J.R., Duarte-Gardea M., Gardea-Torresdey J.L., 2013. Influence of $\mathrm{CeO} 2$ and $\mathrm{ZnO}$ nanoparticles on cucumber physiological markers and bioaccumulation of $\mathrm{Ce}$ and Zn: a life cycle study. Journal of agricultural and food chemistry. 61, 11945-11951. 
634 Zhong X., Zhou S., Zhu Q., Zhao Q., 2011. Fraction distribution and bioavailability of 635 soil heavy metals in the Yangtze River Delta - A case study of Kunshan City in 636 Jiangsu Province, China. Journal of hazardous materials. 198, 13-21.

637

638

639

640

641

642

643

644

645

646

647

648

649

650

651

652

653

654

655

656

657

658

659

660

661

662

663

664

665

666

667

668

669

670

671

672

673 

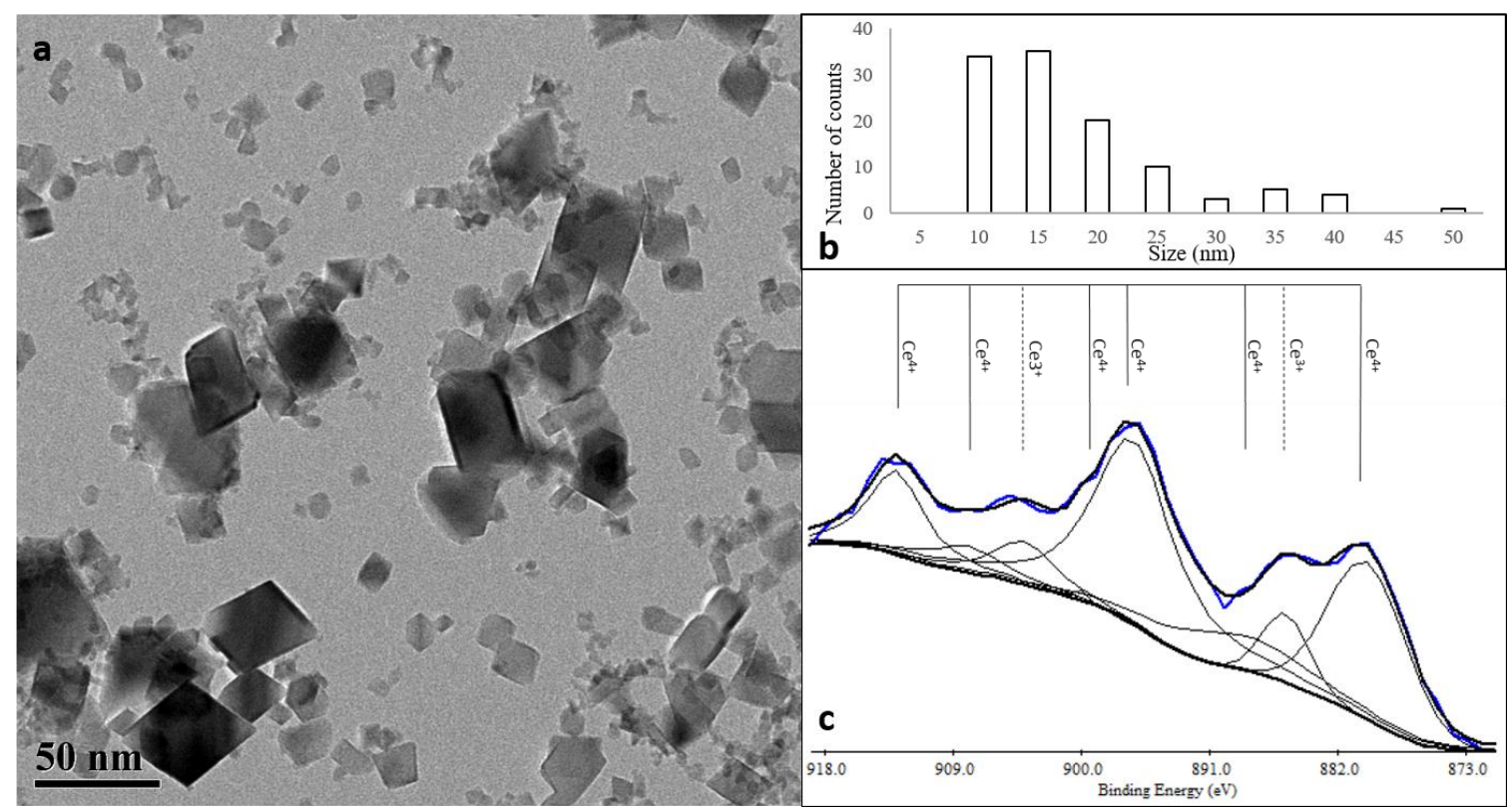

675 Figure 1: Characterization of $\mathrm{CeO} 2 \mathrm{NPs}$. (a) TEM image of $\mathrm{CeO}_{2} \mathrm{NPs}$; (b) The size 676 distribution of the NPs; and (c) The XPS spectra of cerium on the surface of $\mathrm{CeO}_{2} \mathrm{NPs}_{\text {. }}$

677

678

679

680

681

682

683

684

685

686

687

688

689

690

691

692

693

694

695

696

697

698

699

700

701 


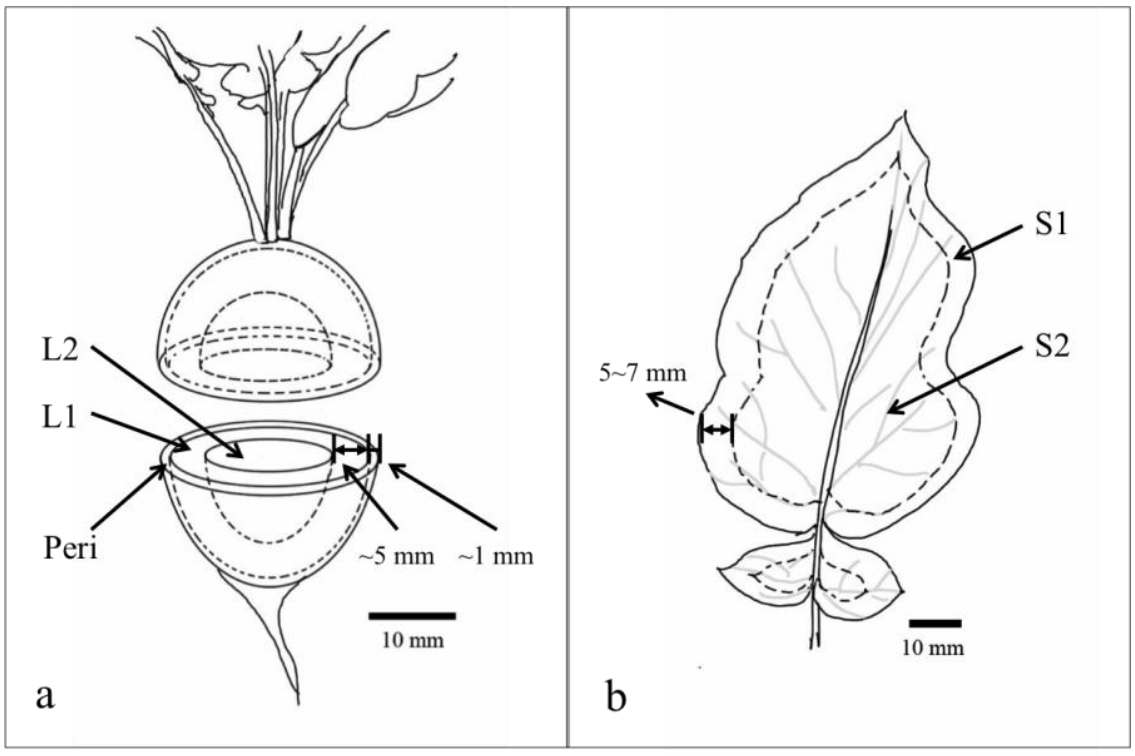

703

704 Figure 2: Schematic illustration of the cutting method of the radish storage root and 705 shoot used for cerium uptake distribution. 


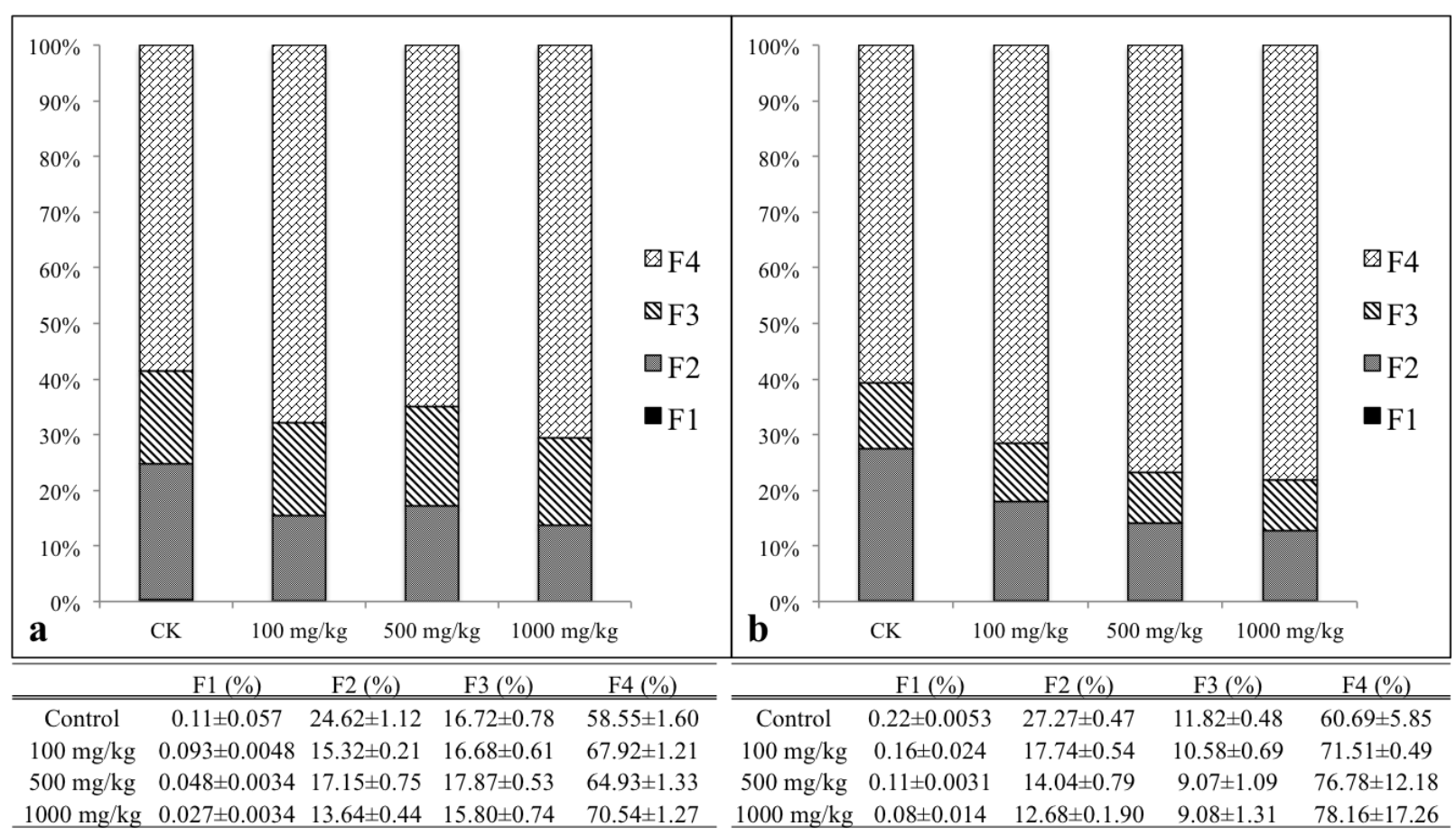

Figure 3: Percentage of cerium fractionation in (a). loamy sand and (b). silty loam determined by the modified BCR sequential extraction procedure. The results shown on the table beneath the figures represent the average and standard error of three replicates. 


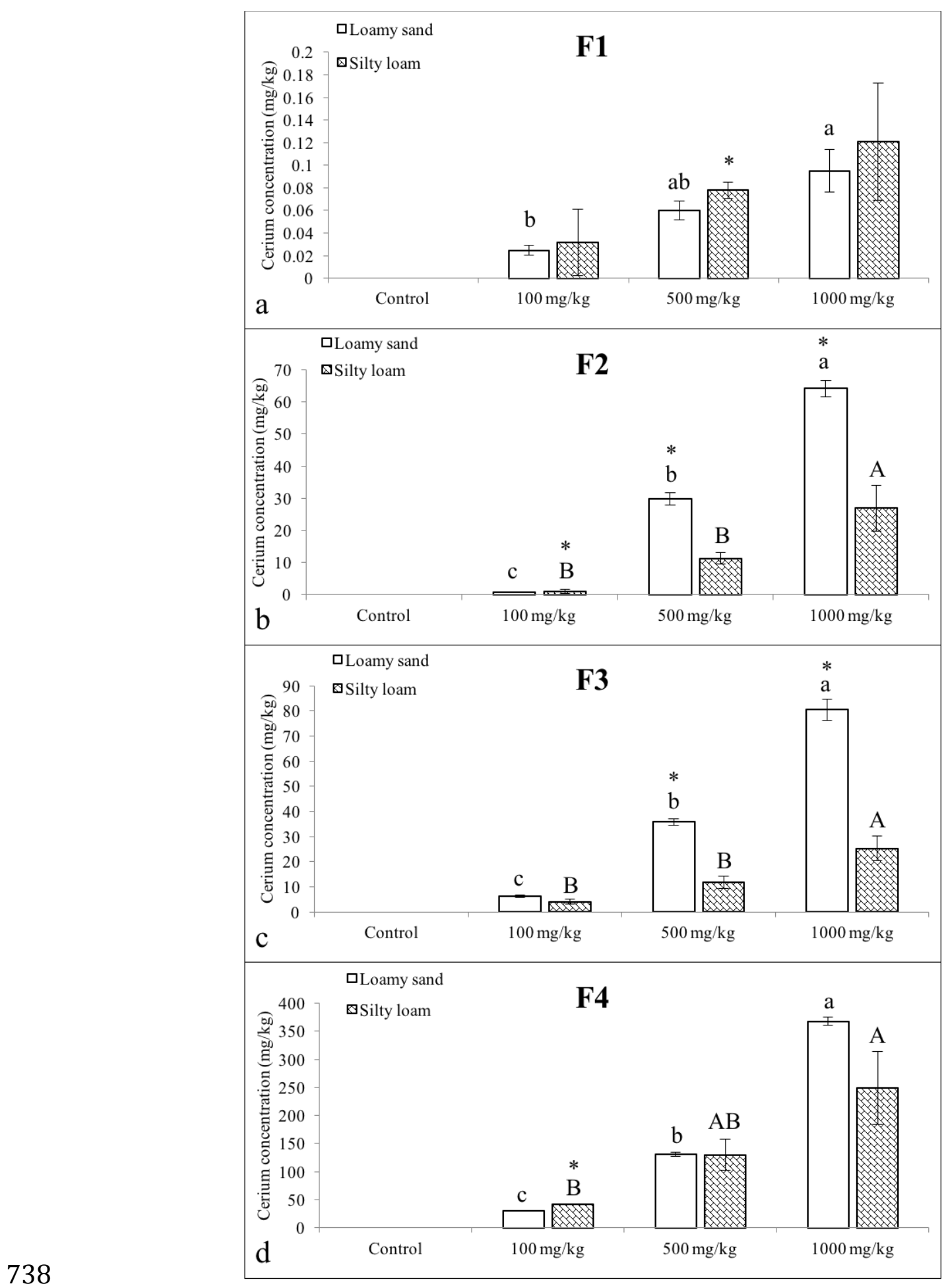

$740 \quad$ Figure 4: Adjusted cerium concentrations in different soil fractions. The error bars

741 represent standard error $(n=3)$. Different letters in lower case and upper case represent

742 significant differences between the treatments in loamy sand and silty loam respectively 743 ( $\mathrm{p}<0.05)$. Asterisks indicate significant differences between two soils at the same $\mathrm{CeO}_{2}$

744 dosing concentration $(\mathrm{p}<0.05)$. 

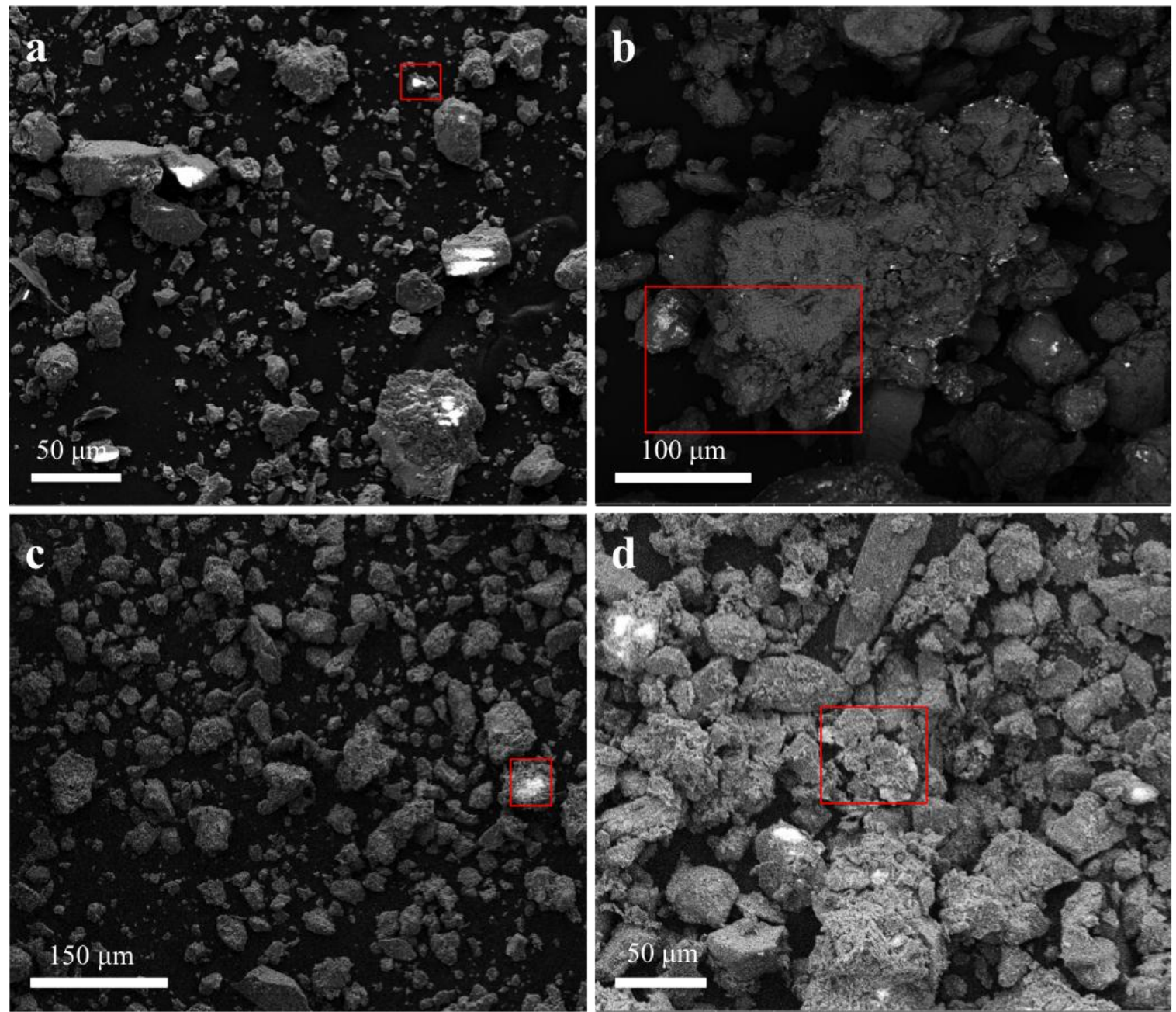

\begin{tabular}{ccccc}
\hline Element & Weight $\%$ in a & Weight $\%$ in b & Weight $\%$ in c & Weight $\%$ in d \\
\hline \hline $\mathrm{O}$ & 61.56 & 56.49 & 62 & 55.32 \\
$\mathrm{Al}$ & 2.48 & 4.04 & 4.85 & 4.43 \\
$\mathrm{Si}$ & 34.85 & 28.65 & 30 & 30.03 \\
$\mathrm{~K}$ & $\mathrm{~N} / \mathrm{A}$ & 0.73 & 3.15 & 0.72 \\
$\mathrm{Ca}$ & $\mathrm{N} / \mathrm{A}$ & 0.76 & $\mathrm{~N} / \mathrm{A}$ & $\mathrm{N} / \mathrm{A}$ \\
$\mathrm{Fe}$ & 1.11 & 2.1 & N/A & 1.45 \\
$\mathrm{Ce}$ & $\mathrm{N} / \mathrm{A}$ & 7.23 & N/A & 8.05 \\
Total & 100 & 100 & 100 & 100 \\
\hline
\end{tabular}

746

747

748

749

750

751

752

753

754

755
Figure 5: SEM images of soil samples of. (a): loamy sand control; (b): loamy sand 1000 $\mathrm{mg} / \mathrm{kg}$; (c): silty loam control; (d): silty loam $1000 \mathrm{mg} / \mathrm{kg}$. Table below images shows the weight percentage of detected elements in selected area (red frames in images) 

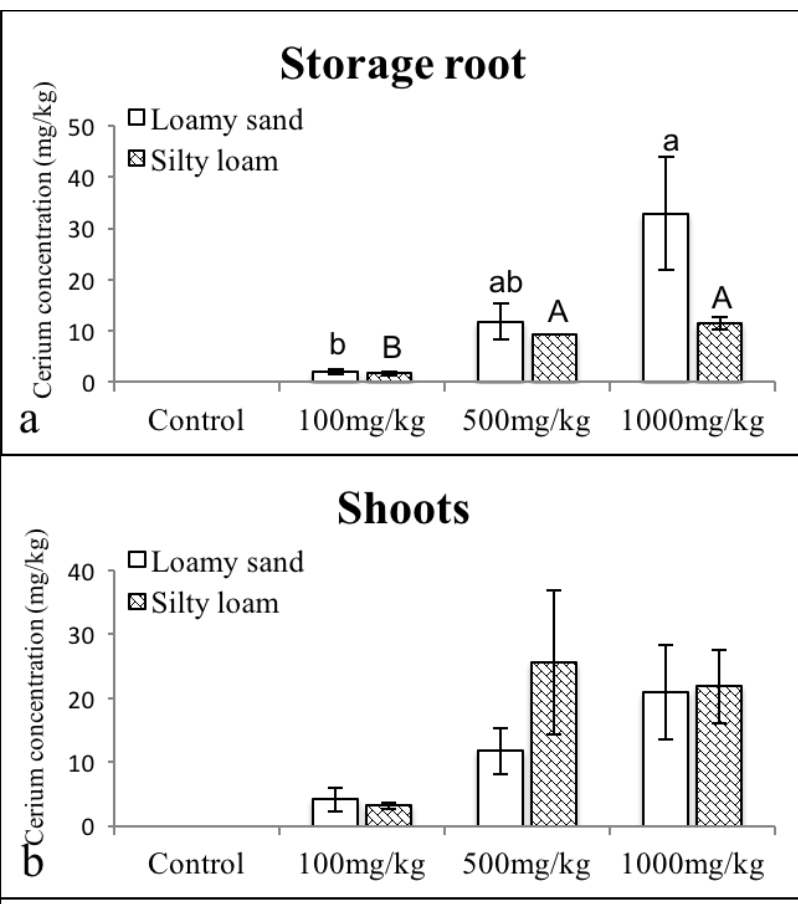

758 Figure 6: Modified cerium concentrations in different radish tissues after the background cerium concentrations in the control plants were subtracted from the corresponding tissues of treated plants. The error bars represent standard error $(n=3)$. Samples without error bars indicate that the error bars are too small to see on the figures. Different letters in lower case and upper case represent significant differences between the treatments in loamy sand and silty loam respectively $(\mathrm{p}<0.05)$. Asterisks indicate significant differences between two kinds of soil at same $\mathrm{CeO}_{2}$ NPs dosing concentration $(\mathrm{p}<0.05)$. 
775 Table 1: The cerium concentration in different parts of radish, data represented the mean

776 and standard error $(n=3)$. Different letters represent significant differences between the

777 treatments

778

\begin{tabular}{ccccccc}
\hline Soil Type & Treatment & Peri $(\mathrm{mg} / \mathrm{kg})$ & $\mathrm{L} 1(\mathrm{mg} / \mathrm{kg})$ & $\mathrm{L} 2(\mathrm{mg} / \mathrm{kg})$ & $\mathrm{S} 1(\mathrm{mg} / \mathrm{kg})$ & $\mathrm{S} 2(\mathrm{mg} / \mathrm{kg})$ \\
\hline \hline \multirow{2}{*}{ Loamy sand } & Control & $11.4 \pm 3.06$ & $7.45 \pm 1.38$ & $11.09 \pm 1.83$ & $18.83 \pm 1.67$ & $8.85 \pm 0.42^{\mathrm{ab}}$ \\
& $500 \mathrm{mg} / \mathrm{kg}$ & $112.9 \pm 52.35$ & $10.88 \pm 1.61$ & $9.4 \pm 1.67$ & $23.12 \pm 0.49$ & $9.81 \pm 1.57^{\mathrm{ab}}$ \\
\hline \multirow{2}{*}{ Silty loam } & Control & $8.91 \pm 0.76$ & $10.43 \pm 2.09$ & $8.07 \pm 2.97$ & $22.9 \pm 4.23$ & $7.00 \pm 0.52^{\mathrm{b}}$ \\
& $500 \mathrm{mg} / \mathrm{kg}$ & $127.06 \pm 56.25$ & $11.49 \pm 1.18$ & $8.61 \pm 0.32$ & $18.26 \pm 3.14$ & $20.58 \pm 7.29^{\mathrm{a}}$ \\
\hline
\end{tabular}

779

780

781

782

783

784

785

786

787

788

789

790

791

792

793

794

795 


\section{Bioavailability of Cerium Oxide Nanoparticles to Raphanus sativus L. in Two Soils}

Weilan Zhang ${ }^{1}$, Craig Musante ${ }^{2}$, Jason C. White ${ }^{2}$, Paul Schwab ${ }^{3}$, Qiang, Wang ${ }^{4}$, Stephen

D. Ebbs ${ }^{5}$, Xingmao $\mathrm{Ma}^{1, *}$

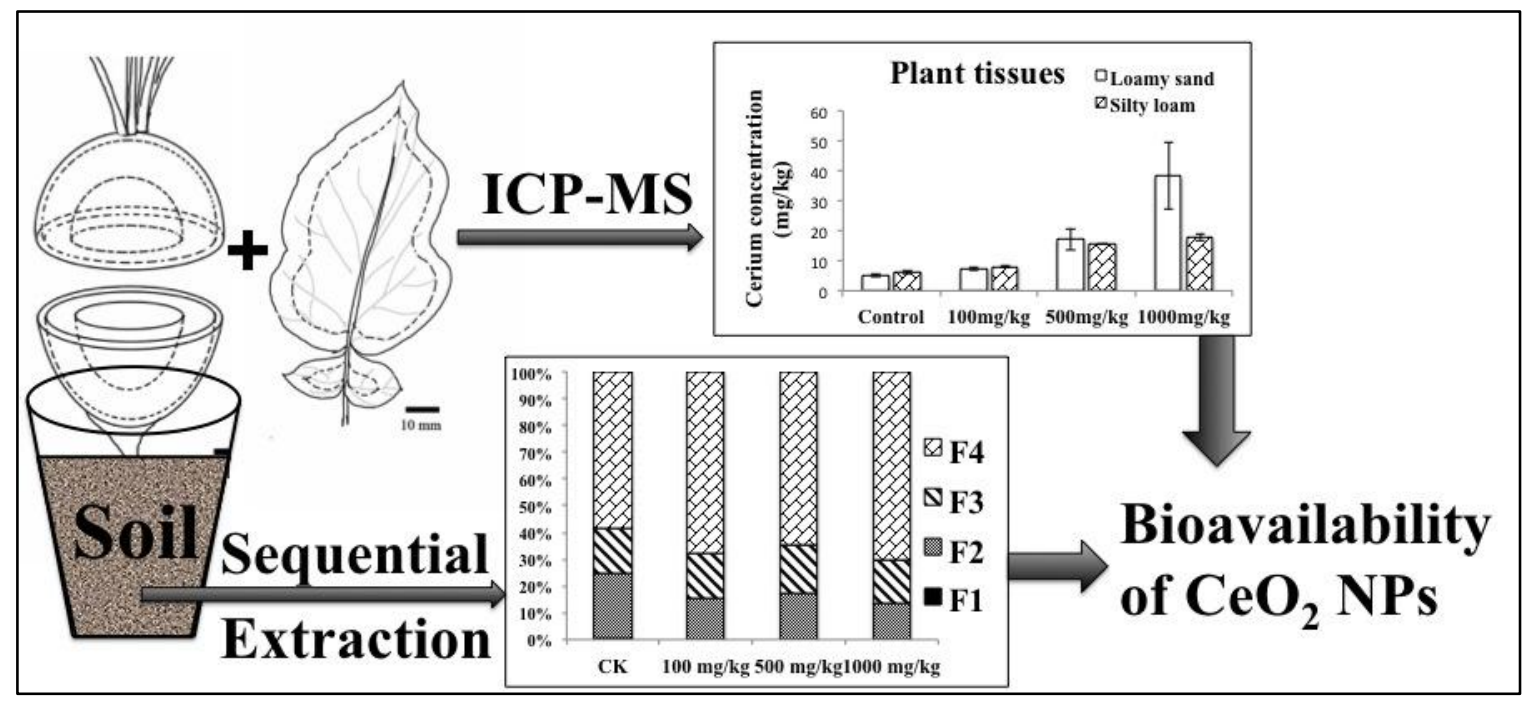

